\title{
ЭТНИЧНОСТЬ И РЕЛИГИОЗНОСТЬ МОЛОДЫХ ЖИТЕЛЕЙ РЕСПУБЛИКИ ТАТАРСТАН (ПО МАТЕРИАЛАМ ЭТНОСОЦИОЛОГИЧЕСКОГО ИССЛЕДОВАНИЯ 2020 г.)
}

\begin{abstract}
Актуальность статьи обусловлена необходимостью изучения этнических и религиозных процессов в молодежной среде в регионах Российской Федерации. Статья написана на материалах этносоииологического исследования, проведенного в Татарстане осенью 2020 г. среди молодых жителей, проживающих в городах республики. Цель статьи заключается в анализе этнических и религиозных установок в среде молодежс Республики Татарстан. Авторами рассмотрень место и роль этнического и конфессионального факторов в структуре социальной идентичности молодых респондентов; обозначены установки на этночентризм и межэтническое взаимодействие, в частности, с мигрантами. Проанализированы вопросы, связанные с религиозным фактором в системе ценностей молодежи. Сделан вывод о том, что этнический и религиозный аспектьл идентичности присутствуют у респондентов во всех исследуемьх группах и актуализированы примерно в равной степени, что указывает на их непротиворечивый характер. Показано, что при довольно высоком уровне этнической солидарности, представители молодежи в целом демонстрируют установки на благоприятное и бесконфликтное межэтническое взаимодействие. Материаль статьи могут быть полезными для сочииологов, психологов, сочиальных и культурных антропологов, политологов, а также представителей органов и структур, курирующих вопросы молодежной политики.
\end{abstract}

Ключевые слова: молодежь, идентичность, этничность, этноцентризм, межэтническое взаимодействие, религиозность, мигранты, установка.

Ссылка при цитировании: Тuтова T.A., Фролова Е.В. Этничность и религиозность молодых жителей Республики Татарстан (по материалам этносоциологического исследования 2020 г.) // Вестник антропологии, 2021. № 4. С. 62-74.

Актуальность изучения стратегий конструирования этничности и религиозности современной молодежи в регионах Российской Федерации обусловлена необходимостью комплексного анализа социальных и психологических процессов, происходящих в молодежной среде, определения интересов и потребностей молодежи,

Титова Татьяна Алексеевна - профессор, д.и.н., профессор кафедры антропологии и этнографии, Казанский (Приволжский) федеральный университет (420008 Казань, ул. Кремлевская, д.18). Эл. почта: tatiana.titova@rambler.ru

Фролова Елена Валерьевна - доцент, к.и.н., доцент кафедры антропологии и этнографии, Казанский (Приволжский) федеральный университет (420008 Казань, ул. Кремлевская, д.18). Эл. почта: elenaieup@mail.ru 
оптимизации условий культурного и этноконфессионального ландшафта для самореализации молодого поколения в регионах Российской Федерации.

Исследования о молодежи, традиционно проводившиеся в нашей стране в основном носили обобщающий характер. В них были даны основные понятия (Иконникова 1974), определены сущность, роль молодёжи в обществе (Иконникова 1969), а также разрабатывалась методология по изучению молодёжи (Лисовский 1971) и молодёжных культур, объединений (Ладатко 1991). Одним из крупных и относительно недавних исследований, посвященных современной молодёжи стала работа, написанная в соавторстве М. К. Горшковым и Ф. Э. Шереги (Горшков, Шерега 2010). Работа затрагивает широкий спектр вопросов от роли молодёжи в современной структуре общества до причин низкой гражданской позиции и этнической, религиозной толерантностиссферу исследовательского интереса российских авторов входят такие аспекты изучения молодежи как анализ структуры социальной идентичности этой группы населения, соотношение общероссийской и этнической идентичностей в ее сознании, особенности социального самочувствия представителей молодого поколения (Авксентьев 2009, Иванова, Шульга 2009). Важным направлением исследований является и изучение особенностей конструирования и реализации конфессиональной идентичности современной молодежи (Большаков 2006, Кобзева 2006, Аникина 2008). Социологов интересуют особенности формирования идентичности молодежи в процессе социализации (Полутин 2013, Ядова 2013). Роль общественных организаций в формировании самосознания представителей молодого поколения также находит отражение в современных исследованиях, в том числе в Республике Татарстан (Титова 2018).

В рамках представленной статьи были проанализированы следующие аспекты социальных установок молодых жителей Татарстана: этническая идентичность и солидарность; конфессиональная идентичность; установки на этноцентризм и особенности межэтнического взаимодействия. Источниками для написания статьи послужили материалы проведенного в 2020 г. этносоциологического исследования респондентов в возрасте 16-30 лет на момент исследования. Для достижения репрезентативности данных было использовано сочетание количественных и качественных методов, а именно: массовый опрос через анкетирование в сочетании с методом фокус-групп. В исследовании приняли участи 3 группы респондентов.

В первую и вторую группы респондентов (учащаяся молодежь) вошли 800 человек 1990 - 2005 гг. рождения, из которых 400 - студенты высших учебных заведений и 400 - студенты организаций среднего профессионального образования Республики Татарстан, проживающих в городах Казань, Набережные Челны, Альметьевск, Нижнекамск. Было проведено 4 фокус-группы с представителями молодежи: 2 - с представителями молодежи, обучающейся в высших учебных заведениях, и 2 - с теми, кто обучается в профессиональных образовательных организациях.

По этническому составу 45,6\% респондентов в этих группах считают себя татарами, 42,9\% - русскими, 11,5\% - представители других народов (чуваши, башкиры, марийцы, мордва, удмурты, украинцы, кряшены, казахи, узбеки, евреи и др.).

Третья группа опрошенных (работающая молодежь) представлена 400 респондентами 1988 - 2002 гг. рождения, из которых 11,8\% имеют среднее образование, $43 \%$ - среднее техническое, $45,3 \%$ - высшее или незаконченное высшее. в этой группе $40 \%$ респондентов работают в сфере услуг, $23 \%$ - в сфере промышленности, строительства и транспорта, 17,8\% - в сфере образования, науки и культуры, 
5\% - служат в армии, МВД и правоохранительных органах, 4,8\% работают в органах государственной власти и местного самоуправления, 2\% - в сфере медицины и здравоохранения, 5,3\% - безработные. 49\% опрошенных в этой группе - татары, 42,3\% - русские, 8,7\% - представители других этнических групп.

В статье использованы в качестве сравнительных результаты исследования учащейся молодежи 2019 г.

\section{Этническая идентичность и солидарность: установки на этноцентризм и межэтническое взаимодействие}

Одной из базовых социальных идентичностей человека является этническая идентичность. Ощущение общности с этнической группой позволяет человеку реализовать потребность в тесных социальных связях, подкрепляет чувство эмоциональной защищенности. Наши исследования 2019 - 2020 гг. показывают, что этническая идентичность является стабильно важным элементом общественного сознания молодых респондентов.

При ответе на вопрос «Насколько важно Вам ошущать себя представителем Вашей нащиональности?» 17,5\% представителей учащейся молодежи выбрали позицию «очень важно», а 36,6\% - «достаточно важно». Таким образом, для 54,1 $\%$ респондентов этническая идентичность является значимой частью социальной идентичности, еще 28,3\% отмечают ее относительную значимость (позиция «не очень важно»); однако около 15\% респондентов выбрали позицию «совершенно не важно». Практически аналогичный результат был получен и при исследовании учащейся молодежи в 2019 г.

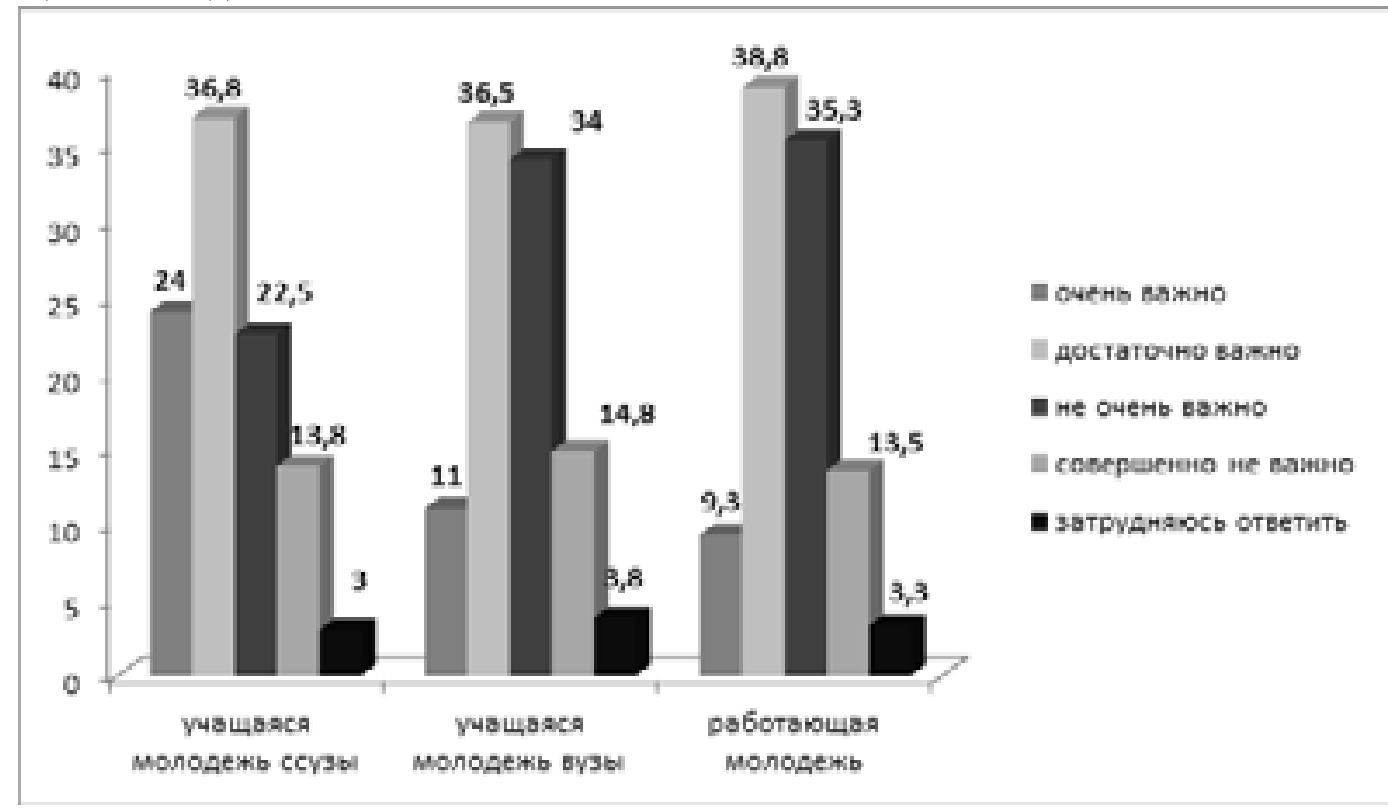

Рис. 1. «Насколько важно Вам ощущзать себя представителем Вашей национальности»? (2020 г., \%)

Следует отметить, что актуализированность этнического аспекта идентичности среди молодых людей, обучающихся в профессиональных образовательных органи- 
зациях, заметно выше, чем среди студентов высших учебных заведений. Так позицию «очень важно» выбрали $11 \%$ студентов вузов и $24 \%$ студентов ссузов (см. рис. 1).

Среди представителей работающей молодежи уровень этнической солидарности в целом несколько ниже - 9,3\% считают, что ощущать себя представителем своей национальности «очень важно», 38,8\% - «достаточно важно». в то же время позицию «совершенно не важно» выбрали 13,5\% опрошенных (см. рис. 1).

Таким образом, респонденты, обучающиеся в профессиональных образовательных организациях, отвечая на вопрос: «Насколько важно Вам ощущать себя представителем Вашей национальности?» несколько чаще выбирают позицию «очень важно»; а студенты высших учебных заведений - «не очень важно», что можно объяснить увеличением социальных контактов в среде высшего учебного заведения и снижением потребности в эмоциональной принадлежности к этнической группе. Такая же тенденция была зафиксирована и в исследовании 2019 г. (Тuтова 2020). Разница в оценках между учащейся и работающей молодежью, по нашему мнению, объясняется тем, что у работающих респондентов этнический аспект может уступать место в иерархии социальных идентичностей профессиональному и семейному аспектам, вследствие чего этническая идентичность в некоторой степени утрачивает свои позиции.

«Лично для меня этнический вопрос довольно-таки важный, потому что я сам по национальности татарин...» (фокус-группа, студенты вузов, г. Набережные Челны).

"Думаю, нужно уважать свой народ, чтить их память, потому что наши предки не зря развивали все это. То есть мы татары, нужно уважать своих предков, то, к чему они стремились, уважать свой народ, свой язык родной» (фокус-группа, студенты ссузов, г. Казань).

«Для меня важна моя национальная принадлежность. Как раз актуальный вопрос, только вчера с молодым человеком обсуждали. Для меня важно ощущать себя русской...» (фокус-группа, работающая молодежь, г. Казань).

«По народам отношу себя к татарам, но я не разделяю людей на народы для себя, считаю, что все люди равные» (фокус-группа, работающая молодежь, г. Казань).

В целом, мы видим, что для более $80 \%$ молодежи этническая идентичность важна, но в разной степени. Значительная доля (более трети опрошенных) выбирает позицию «достаточно важно». Лишь 14,3\% среди учащихся респондентов и $13,5 \%$ среди работающих выбрали позицию «совершенно не важно». Таким образом, можно констатировать, что в среде молодых людей потенциал солидарности, связанный с этническим фактором довольно высок.

Вопрос: «В какой степени Вы согласны с утверждением: «Нормально считать, что твой народ лучше, чем все остальные»?» является индикатором актуализированности установок на этноцентризм. Среди представителей учащейся молодежи по сравнению с исследованием 2019 г. выросло количество как полностью согласных, так и полностью не согласных с данным утверждением (см. рис. 2). 


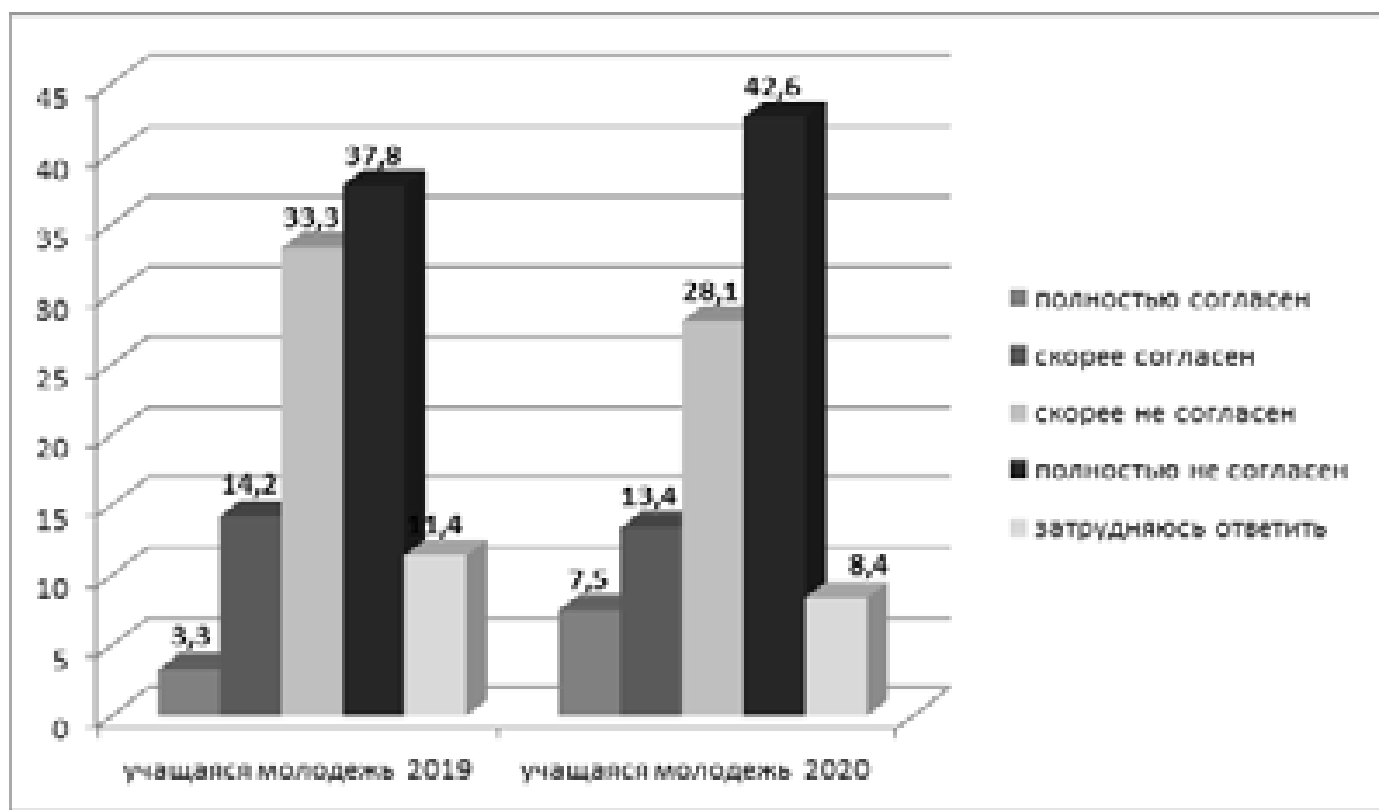

Рис. 2. «В какой степени Вы согласны с утверждением: «Нормально считать, что твой народ лучше чем все остальные»? (2019-2020 г2., \%).

Полученные данные показывают, что представители работающей молодежи и студенты высших учебных заведений демонстрируют меньшую выраженность этноцентристских установок, нежели студенты профессиональных образовательных организаций (см. рис. 3).

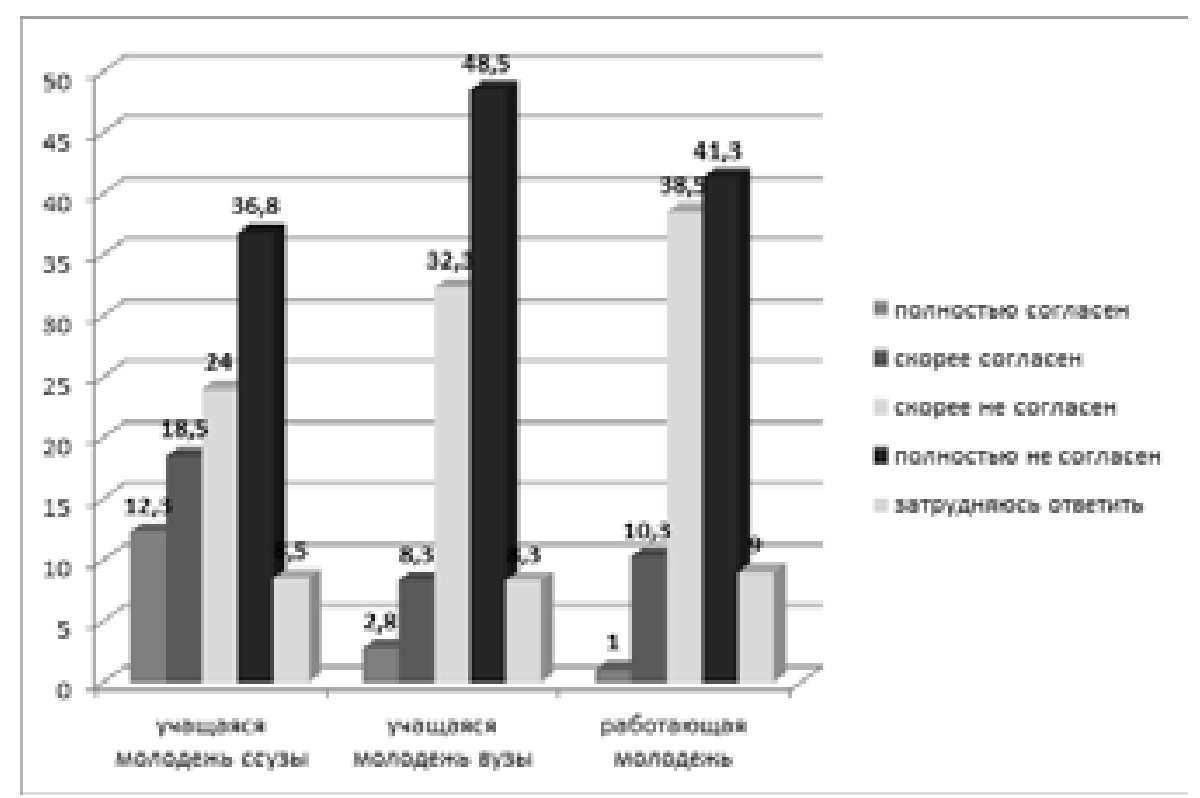

Рис. 3. «В какой степени Вы согласны с утверждением: «Нормально считать, что твой народ лучше, чем все остальные»? (2020 2., \%).

Одним из индикаторов состояния межнациональных отношений является отношение к мигрантам. Это актуальная тема для Татарстана, ибо миграционный ландшафт республики весьма разнообразен и многогранен. В 2020 г. увеличилось коли- 
чество респондентов, считающих, что мигранты должны иметь те же права, что и местные жители (позицию «полностью согласен» и «скорее согласен» выбрали на 5\% респондентов больше, чем в 2019 г.) (см.рис.4).

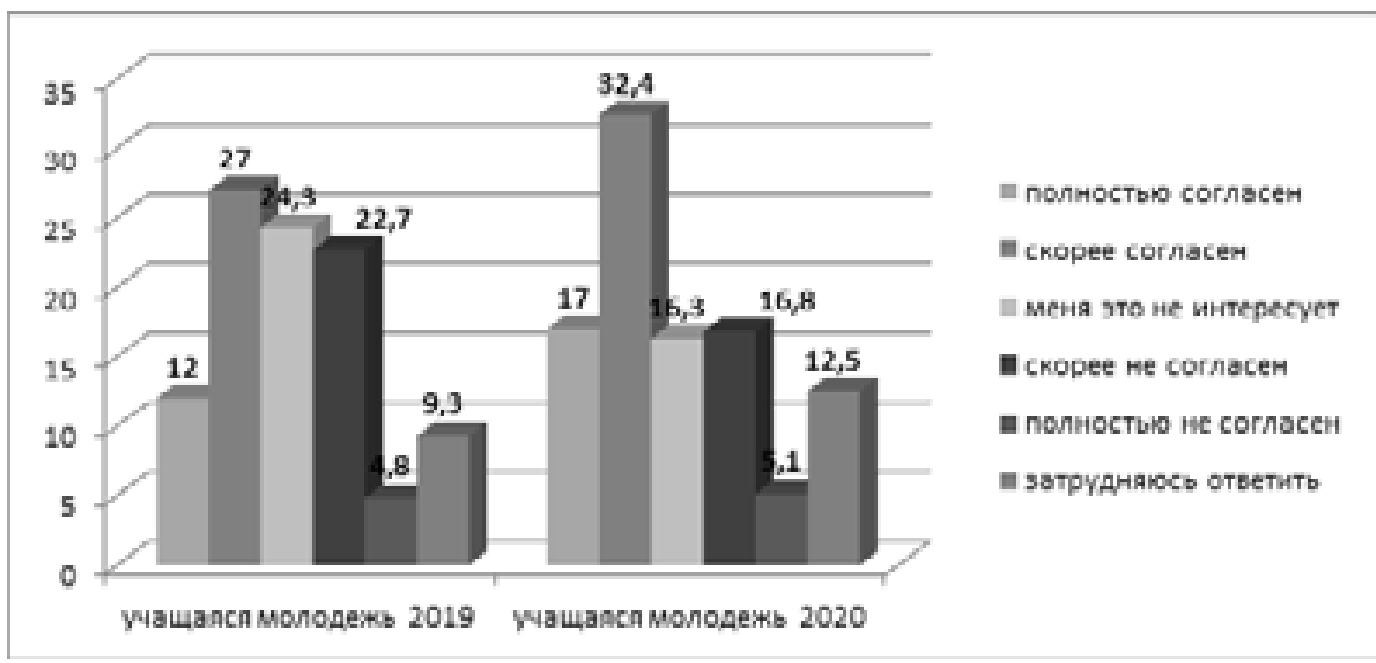

Рис. 4. «Как Bы относитесь к идее: «Мигранты из других стран должнь иметь те же права, что и местные жители, кроме права голосовать на выборах»?

$$
\text { (2019-2020 22., \%). }
$$

Студенты высших учебных заведений, согласно результатам исследования 2020 г., демонстрируют более выраженное согласие с позицией о необходимости предоставления мигрантам одинаковых прав с местными жителями (по совокупности позиций «полностью согласен» и «скорее согласен») (см. рис. 5).

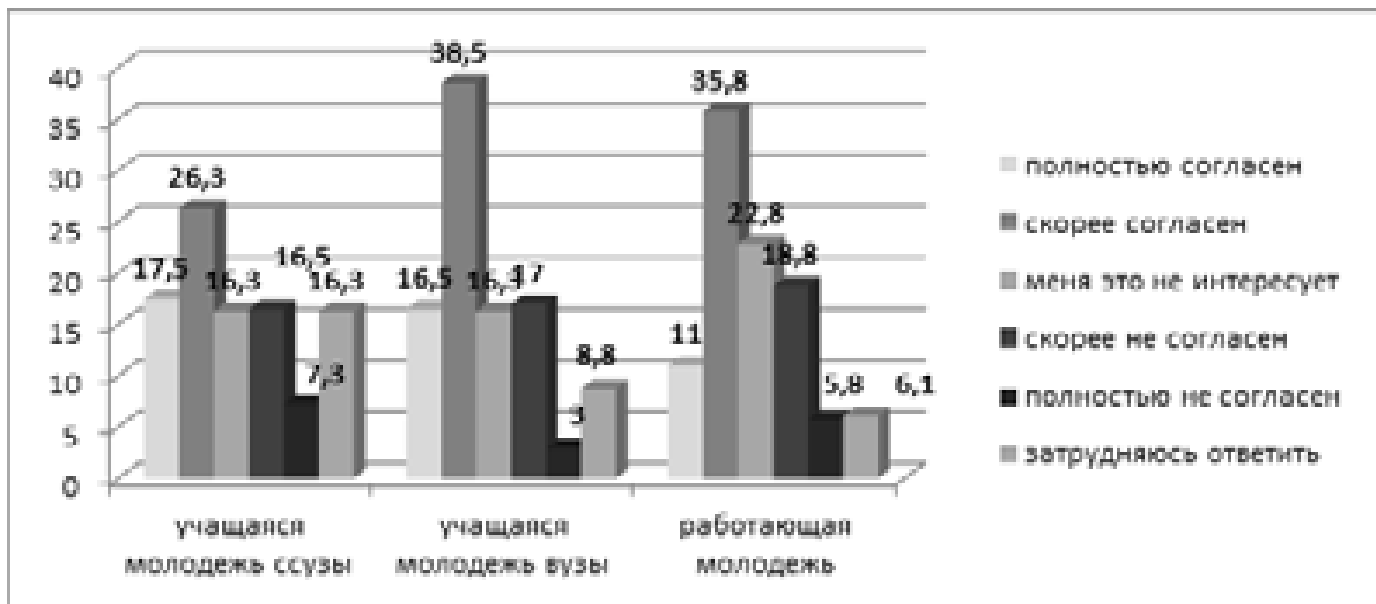

Рис. 5. «Как Вы относитесь к идее: «Мигранты из других стран должны иметь те же права, что и местные жители, кроме права голосовать на выборах»? (2020 г., \%)

Представители работающей молодежи занимают более осторожную позицию в вопросе предоставления мигрантам одинаковых прав с местным населением. Это выражается в том, что среди этой группы меньше респондентов, выбирающих позицию «полностью согласен», они чаще выбирают позицию «меня это не интересует» (см. рис. 5). 
Количество полностью не согласных с указанной позицией больше всего в группе представителей молодежи, обучающейся в средних специальных учебных заведениях, и составляет 7,3 \%; в этой же группе больше всего респондентов, затрудняющихся с ответом (см. рис. 5).

В вопросе, связанном с культурной адаптацией мигрантов, респонденты высказываются определеннее: около $80 \%$ опрошенных представителей учащейся молодежи в той или иной степени согласны с утверждением, что мигрантам надо помогать приспосабливаться к условиям местной жизни (см. рис. 6).

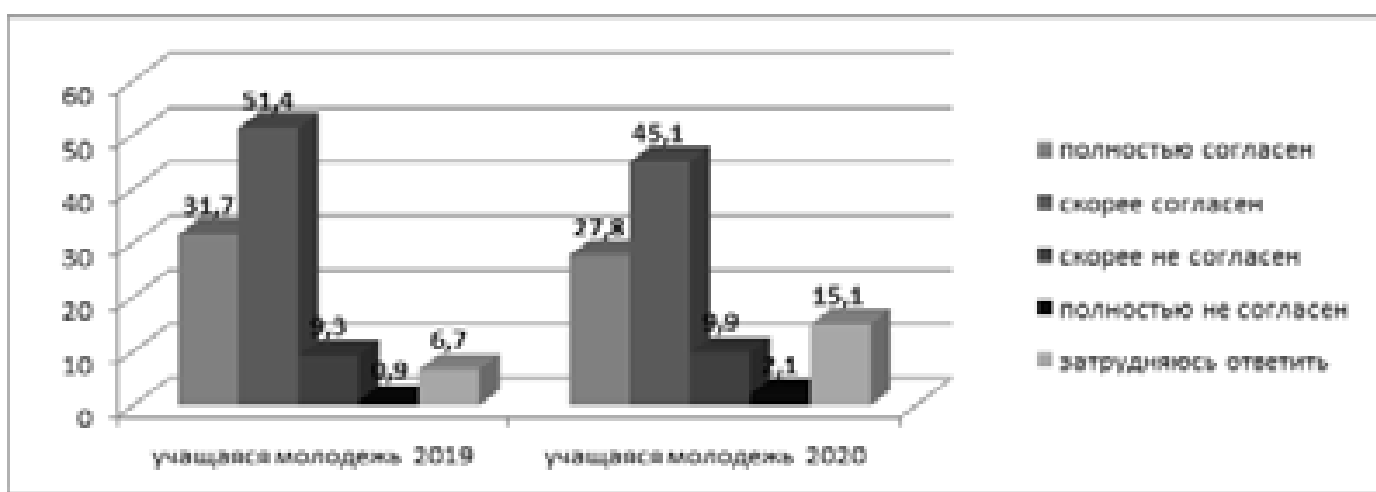

Рис. 6. «В какой степени Вы согласны с утверждением:

«Мигрантам надо помогать приспосабливаться к условиям местной жизни (нашим правилам, традициям, нормам и т.n.)»? (2019-2020 г2., \%).

В вопросе о необходимости оказывать помощь мигрантам для их более успешной адаптации, значимых расхождений между студентами высших учебных заведений и представителями работающей молодежи практически нет (см. рис.7). Студенты профессиональных образовательных организаций реже выбирают позицию «скорее согласен» и чаще затрудняются с ответом (см. рис.7).

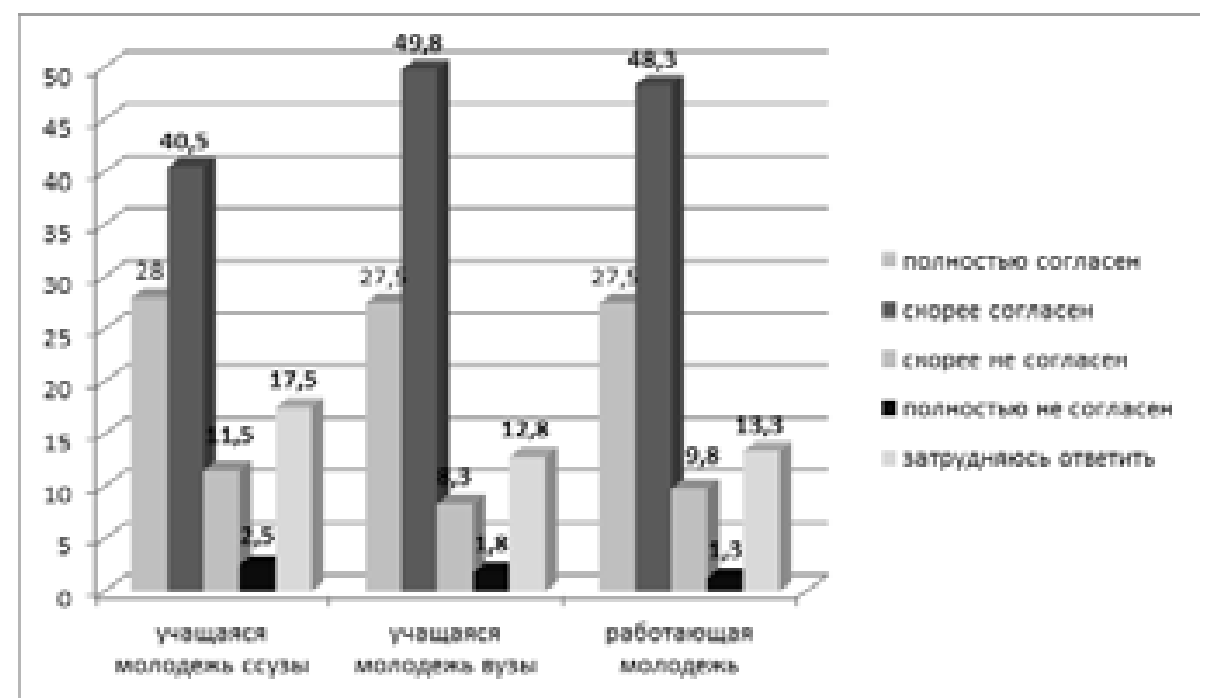

Рис. 7. «В какой степени Вы согласны с утверждением:

«Мигрантам надо помогать приспосабливаться к условиям местной жизни (нашим правилам, традициям, нормам и т.n.)»? (2020 г., \%) 
Полученные данные показывают, что, при довольно высоком уровне этнической солидарности, представители молодежи в целом демонстрируют установки на благоприятное и бесконфликтное межэтническое взаимодействие. Об этом свидетельствует достаточно слабая актуализированность этноцентричных установок, толерантное либо индифферентное отношение к представителям сообществ мигрантов. При этом у студентов профессиональных образовательных организаций более высок уровень этноцентризма, то есть некритического предпочтения собственного народа, что, в сочетании с достаточно высоким уровнем этнической солидарности может послужить основанием для возникновения межэтнической напряженности. Представители работающей молодежи демонстрируют меньшую выраженность этноцентристких установок, но, в то же время, достаточно осторожно относятся к мигрантам.

\section{Конфессиональная идентичность и религиозность}

Конфессиональная идентичность также является фактором социальной интеграции. Около двух третей опрошенных относят себя к той или иной религии (см. рис. 8).

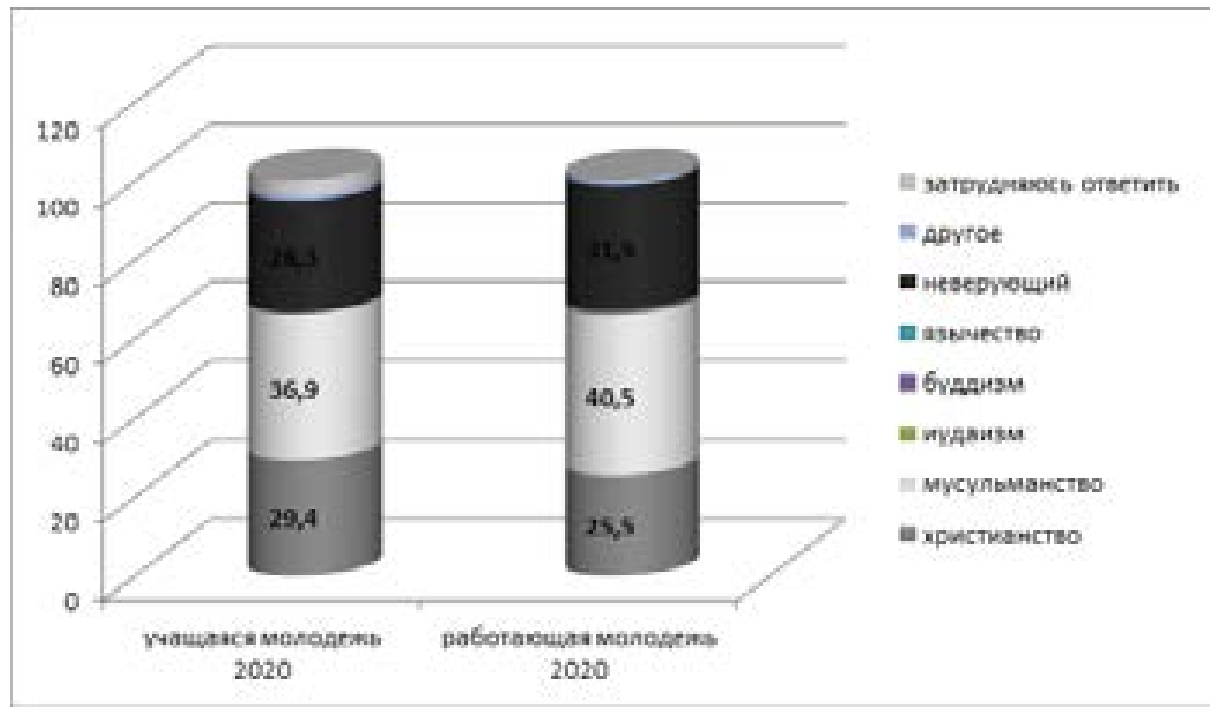

Рис. 8. «К какой религии Вы себя относите?» (2020 г., \%).

Индикатором значимости религиозной идентичности как консолидирующего фактора, показателем потребности в чувстве религиозной общности, является вопрос: «Насколько значима для Вас религия?». В целом, как и в 2019 г., около 60\% представителей учащейся молодежи говорят о значимой роли религии в своей жизни (см. рис. 9).

При этом, как и в случае с этничностью, студенты профессиональных образовательных организаций чаще выбирают позицию «очень значима» (см. рис. 10).

Среди представителей работающей молодежи больше респондентов, выбирающих позицию «не очень значима», и меньше тех, кто выбрал вариант «очень значима». Здесь можно применить то же объяснение, что и для расхождения показателей между представителями учащейся и работающей молодежи в уровне этнической солидарности: в структуре идентичности работающих респондентов на первый план 
выходят профессиональные и семейные аспекты идентичности, а значимость этнической и религиозной идентичности может снижаться (см.рис.10).

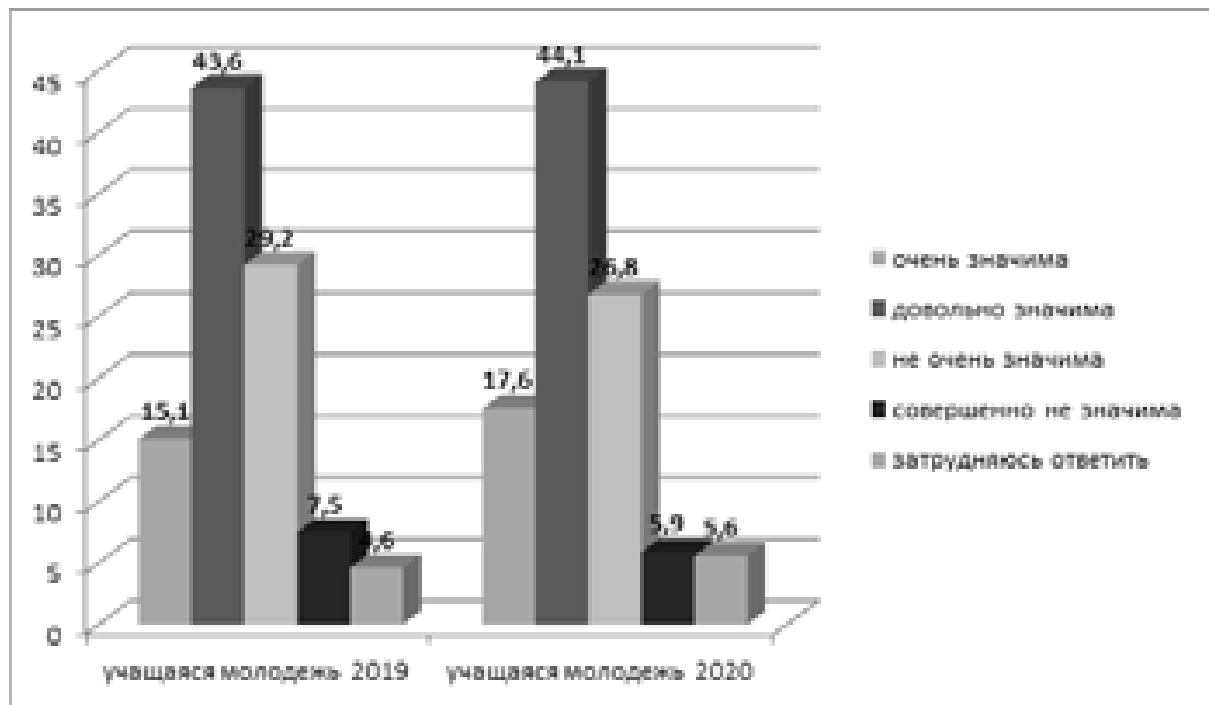

Рис. 9. «Насколько значима для Вас религия?»

(2019-2020 г2., \% из числа обозначивших свою религиозную принадлежность).

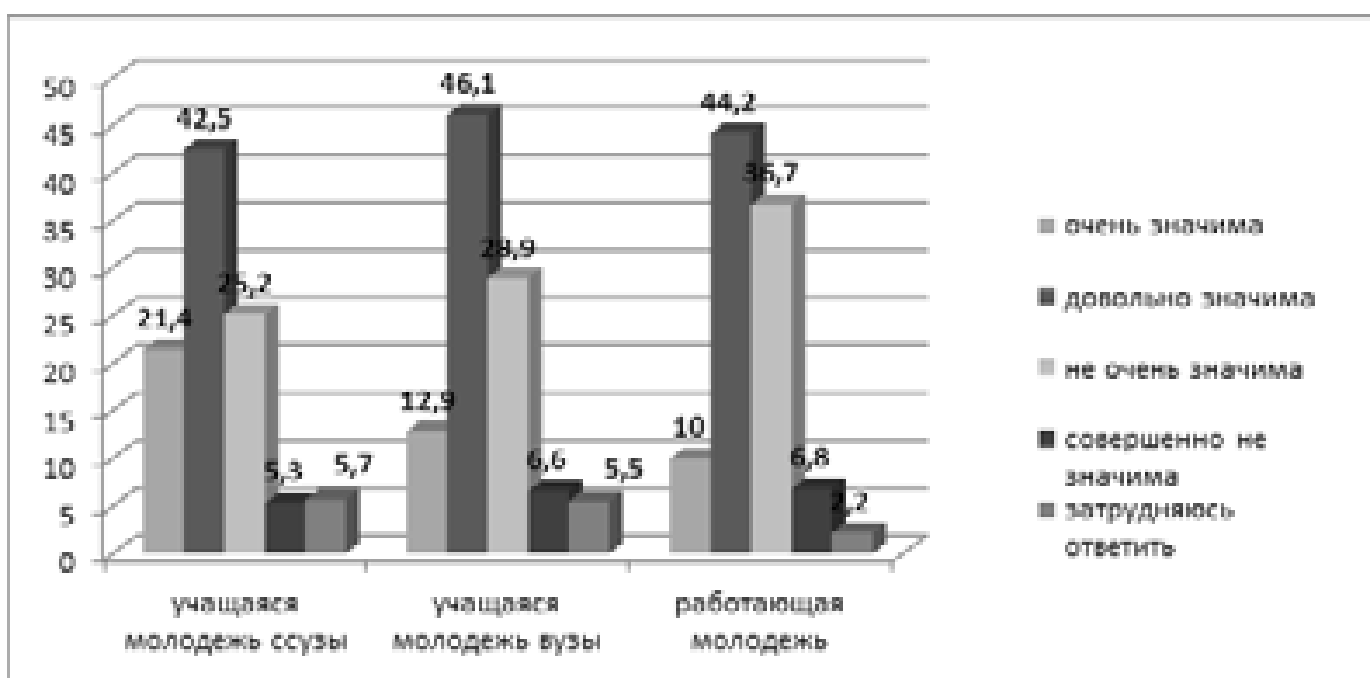

Рис. 10. «Насколько значима для Вас религия?»

(2020 г., \%, из числа обозначивших свою религиозную принадлежность).

В целом, религиозный фактор является достаточно значимым в системе ценностей современной молодежи. Более $40 \%$ опрошенных во всех исследуемых группах выбирают позицию «довольно значима». Около 70\% молодых людей во всех группах относят себя к верующим. Можно заключить, что конфессиональный аспект идентичности в сознании респондентов несколько более актуализирован, нежели этнический.

Полученные материалы также показывают, что для респондентов-татар конфессиональная и этническая идентичность более значима, чем для респондентов-русских и представителей других народов, принявших участие в исследовании. Эта тенденция нашла подтверждение и в глубинных интервью: 
«Я мусульманин и все аспекты, которые как бы мусульманские, допустим, не есть свинину, молиться и прочее, я, конечно, не всё выполняю, к сожалению, но это дело времени. В скором времени, я, надеюсь, к этому приду, но, по крайней мере, одно правило - «харам», то что свинина - «харам», это я выполняю. Я стараюсь придерживаться канонов этих. Не всегда, конечно, получается, есть свои соблазны, но мы работаем над собой» (фокус-группа, студенты вузов, г. Набережные Челны).

«Я мусульманка, татарка, несомненно, я горжусь тем, что я мусульманка, потому что это как-то придаёт уверенности, молитвы в какое-то такое тяжёлое время, всё равно, если ты во что-то веришь как-то более спокойнее на душе» (фокус-группа, студенты вузов, г. Набережные Челны).

«Я русская и христианка, но как бы это не влияет на меня как-то очень сильно, не несет большой значимости, то есть я не ношу крестик, например, ничего такого не соблюдаю особо» (фокус-группа, работающая молодежь, г. Казань).

«Лично для меня религия на первом месте не может быть, потому что для меня на первом месте то, что нужно быть человечным. Можно быть человеком религиозным, но не человечным. А так, я православная официально. Но не скажу, еще раз повторюсь, что это для меня как-то очень важно» (фокус-группа, работающая молодежь, г. Казань).

Учитывая, что к вере и религии, как правило, люди приходят в более зрелом возрасте, уровень религиозности современной молодежи нашей республики, на наш взгляд, достаточно высок.

Полученные данные об этнической и религиозной идентичности респондентов позволяют обозначить непротиворечивый тренд на сосуществование довольно высокого уровня этнической солидарности и религиозной идентичности в сознании респондентов. При этом этнический и религиозный аспекты идентичности в большей степени актуализированы у респондентов-татар; а также в большей степени у респондентов, обучающихся в профессиональных образовательных организациях. Это объясняется тем, что в структуре идентичности работающих респондентов на первый план выходят профессиональные и семейные аспекты идентичности, а значимость этнической и религиозной идентичности может снижаться.

Меньшая актуализированность этнического аспекта идентичности среди молодых людей, обучающихся в высших учебных заведениях можно объяснить увеличением социальных и межэтнических контактов в среде высшего учебного заведения, что снижает потребность в эмоциональной принадлежности к этнической группе.

Представители молодежи демонстрируют установки на благоприятное и бесконфликтное межэтническое взаимодействие, что позволяет прогнозировать отсутствие напряженности в этническом поле республики в ближайшей перспективе.

\section{Научная литература}

Авксентьев В.A. Социальное самочувствие молодежи Северного Кавказа // Молодежь России: Сборник рефератов статей из периодических изданий за 2008 г. М.: Российская государственная библиотека для молодежи, 2009. С. 17-20. 
Аникина А.В. Религиозность современной студенческой молодежи (на примере Нижегородской области). Дисс. ... к.социол.н. Нижний Новгород, 2008. 205 с.

Большаков E.A. Отношение к религии студенческой молодежи среднерусского региона (на примере Ивановской области). Дисс. ... к.социол.н. Нижний Новгород, 2006. 182 с.

Горшков М.К. Молодежь России: социологический портрет. М.: ЦСПиМ, 2010. 592 с.

Козлов В.Е., Фролова Е.В., Вятчина М.В. Диаспоры и сообщества мигрантов в Республике Татарстан: этносоциологические очерки. Ч. ІІІ. Казань: ЗАО «Мир без границ», ООО Глаголь, 2016. $152 \mathrm{c}$.

Иванова С.Ю. Гражданский портрет молодежи ЮФО // Вестник Южного научного центра, 2009. Т. 5. № 3. С.112-119.

Иконникова С.Н. Молодежь. Социологический и социально-психологический анализ. Л.: Издательство Ленинградского университета, 1974. 167 с.

Иконникова С.Н. Молодёжь о себе, о своих сверстниках: социологическое исследование. Л.: Лениздат, 1969. $133 \mathrm{c.}$

Кобзева Н.А. Религиозность студенческой молодежи в трансформируемой России: социологический анализ. Дисс. ... к.социол.н. М., 2006. 167 с.

Ладатко А.А. Неформальные молодежные объединения. М.: Высш. шк., 1991. 47 с.

Лисовский В.Т. Советская молодежь: идеалы и стремления. М.: Знание, 1971. 32 с.

Покида Н.И. (науч. ред.) Молодежь новой России: образ жизни и ценностные приоритеты. М.: Институт социологии РАН, 2014. 96 с.

Полутин С.В. Молодежь в системе социального воспроизводства: социологический анализ. Саранск: Изд-во Мордов. Ун-та, 2013. 193 с.

Титова Т.А., Фролова Е.В., Савина А.С. Ключевые механизмы формирования этнической и гражданской идентичности современной молодёжи в общественных организациях Республики Татарстан // Исторические, философские, политические и юридические науки, культурология и искусствоведение. Вопросы теории и практики, 2018. № 5 (91). С. 53-56.

Титова T.A., Фролова Е.В., Гущฺина Е.Г. Этническая идентичность и установки на межэтническое взаимодействие в среде молодежи Республики Татарстан // Казанский педагогический журнал, 2020. № 2. С. 185-290.

Ядова Е.Н. Особенности и практическая значимость характеристик идентичности современной молодежи в процессе социализации // Актуальные проблемы психологии труда и развития. Вестник Балтийской педагогической Академии. 2013. Вып. 50. С. 127-131.

Titova, Tatiana A., and Elena V. Frolova

\section{Ethnicity and Religiosity of the Young Residents of the Republic of Tatarstan Based on the Ethno-sociological Study of 2020}

\section{DOI: 10.33876/2311-0546/2021-4/62-74}

The purpose of the article is to analyze ethnic and religious attitudes among the youth of the Republic of Tatarstan. The article is based on the ethno-sociological study conducted in Tatarstan in the autumn of 2020 among young residents living in the cities of the republic. The authors discuss role of ethnic and confessional factors in the structure of social identity of young respondents and identify the attitudes towards ethnocentrism and interethnic interaction, particularly with migrants. The religious factor in the value system of young people is analyzed. It is concluded that the ethnic and religious aspects are consistent and equally important for self-identity among all the studied groups. It is shown that despite fairly strong ethnic solidarity, young people are generally disposed to favorable and conflict-free interethnic interaction. The article can be useful for sociologists, psychologists, social and cultural anthropologists, political scientists, and representatives of the structures in charge of youth policy issues. 
Keywords: youth, identity, ethnicity, ethnocentrism, interethnic interaction, religiosity, migrants, attitude

For Citation: Titova, T.A., E.V. and Frolova. 2021. Ethnicity and Religiosity of the Young Residents of the Republic of Tatarstan Based on the Ethno-sociological Study of 2020. Herald of Anthropology (Vestnik Antropologii) 4: 62-74.

Author Info: Titova, Tatiana A. - Professor, Doctor of Hist., Professor of the Department of History of Tatarstan, Archeology and Ethnography, Kazan Federal University (Kazan, Russia). Email: tatiana.titova@rambler.ru.

Frolova, Elena V. - PhD (Hist.), Associate Professor of the Department of History of Tatarstan, Archeology and Ethnography, Kazan Federal University (Kazan, Russia). Email: elenaieup@mail.ru

\section{References}

Avksentiev, V.A. 2009. Sotsial'noe samochuvstvie molodezhi Severnogo Kavkaza [Social well-being of youth of the North Caucasus] In Molodezh' Rossii: Sbornik referatov statei iz periodicheskikh izdanii za $2008 \mathrm{~g}$. [Youth of Russia: Collection of abstracts of articles from periodicals for 2008], 17-20. Moscow: Rossiiskaia gosudarstvennaia biblioteka dlia molodezhi.

Anikina, A.V. 2008. Religioznost'sovremennoi studencheskoi molodezhi (na primere Nizhegorodskoi oblasti) [Religiousness of modern student youth (on example of the Nizhny Novgorod region), PhD diss., Nizhny Novgorod.

Bolshakov, E.A. 2006. Otnoshenie k religii studencheskoi molodezhi srednerusskogo regiona (na primere Ivanovskoi oblasti): dissertatsiia ... kandidata sotsiologicheskikh nauk. [The attitude to religion of student youth of the Central Russian region (on the example of the Ivanovo region)], PhD diss., Nizhny Novgorod.

Gorshkov, M.K. 2010. Molodezh'Rossii: sotsiologicheskii portret. [Youth of Russia: sociological portrait]. Moscow: Center for social forecasting and marketing.

Ivanova, S.Iu. 2009. Grazhdanskii portret molodezhi IuFO [Civil portrait of the youth of the Southern Federal District]. Vestnik Iuzhnogo nauchnogo tsentra 5 (3): 112-119.

Ikonnikova, S.N. 1974. Molodezh'. Sotsiologicheskii i sotsial'no-psikhologicheskii analiz [Youth. Sociological and socio-psychological analysis]. Leningrad: Izdatel'stvo Leningradskogo universiteta.

Ikonnikova, S.N. 1969. Molodezh'o sebe, o svoikh sverstnikakh: sotsiologicheskoe issledovanie [Youth about themselves, about their peers: a sociological study]. Leningrad: Lenizdat.

Kobzeva, N.A. 2006. Religioznost' studencheskoi molodezhi v transformiruemoi Rossii: sotsiologicheskii analiz [Religiousness of student youth in transforming Russia: sociological analysis], PhD diss., Moscow.

Kozlov, V.E., E.V. Frolova and M.V. Viatchina (ed). 2016. Diaspory i soobshchestva migrantov v Respublike Tatarstan: etnosotsiologicheskie ocherki [Diasporas and migrant communities in the Republic of Tatarstan: ethnosociological essays]. Part III. Kazan: ZAO "Mir bez granits', OOO Glagol".

Ladatko, A.A. 1991. Neformal'nye molodezhnye ob"edineniia [Informal youth associations]. Moscow: Higher school.

Lisovskii, V.T. 1971. Sovetskaia molodezh': idealy i stremleniia [Soviet youth: ideals and aspirations]. Moscow: Znanie.

Pokida, N.I. (ed.). 2014. Molodezh' novoi Rossii: obraz zhizni i tsennostnye prioritety [Youth of the new Russia: lifestyle and value priorities]. Moscow: Institute of sociology of the Russian Academy of Sciences. 
Polutin, S.V. 2013. Molodezh'v sisteme sotsial'nogo vosproizvodstva: sotsiologicheskii analiz [Youth in the system of social reproduction: sociological analysis]. Saransk: Mordovia University Publishing House.

Titova, T.A., E.V. Frolova, and A.S. Savina 2018. Kliuchevye mekhanizmy formirovaniia etnicheskoi i grazhdanskoi identichnosti sovremennoi molodezhi $\mathrm{v}$ obshchestvennykh organizatsiiakh Respubliki Tatarstan [Key mechanisms of formation of ethnic and civil identity of modern youth in public organizations of the Republic of Tatarstan]. Istoricheskie, filosofskie, politicheskie $i$ iuridicheskie nauki, kul'turologiia i iskusstvovedenie. Voprosy teorii i praktiki 5 (91): 53-56.

Titova, T.A., E.V. Frolova, and E.G. Gushchina. 2020. Etnicheskaia identichnost' i ustanovki na mezhetnicheskoe vzaimodeistvie v srede molodezhi Respubliki Tatarstan [Ethnic identity and attitudes towards interethnic interaction among the youth of the Republic of Tatarstan]. Kazanskii pedagogicheskii zhurnal 2: 185-290.

Yadova (Iadova), E.N. 2013.Osobennosti i prakticheskaia znachimost' kharakteristik identichnosti sovremennoi molodezhi $\mathrm{v}$ protsesse sotsializatsii [Features and practical significance of characteristics of identity of modern youth in the process of socialization]. Aktual'nye problemy psikhologii truda i razvitiia. Vestnik Baltiiskoi pedagogicheskoi Akademii 50: 127-131. 